УДК 346.548

DOI https: / / doi.org/10.32837/yuv.v0i3.961

\author{
О. Білий, \\ аспірант кафедри господарського права і процесу \\ Національного університету «Одеська юридична академія»
}

\title{
ВИНА СУБ'ЄКТІВ ГОСПОДАРЮВАННЯ ЯК УМОВА ВІДПОВІДАЛЬНОСТІ ЗА БЕЗПЕКУ ПРОДУКЦІї
}

Незаконний оборот непродовольчих товарів є загальносвітовою проблемою, а завдання забезпечення захисту внутрішніх ринків носить інтернаціональний характер. В Україні незаконний оборот промислової і харчової продукціï на внутрішньому ринку $€$ серйозною проблемою на шляху становлення i розвитку національної економіки, а протидія такого роду діяльності має бути важливою складовою економічної політики держави. Недостатньо жорстке законодавство України, відсутність перевірок з боку державних контролюючих органів (діє мораторій), незначний розмір штрафів у співвідношенні 3 можливими прибутками від виробництва фальсифікованої/контрафактної продукції для недобросовісних виробників, низький рівень інформованості споживачів щодо вимог до якості продукції, створює додаткові передумови для наведення українського ринку неякісними товарами. Пом'якшення законодавства до правопорушень у господарській діяльності викликає певні дискусії і викликало інтерес автора цієї статті. Увага господарського права до проблем безпечності та якості продукції проявляється у наступному: по-перше, продукція як певний вид товару має економіко-правову природу; по-друге, особами, що задіяні у процедурах вироблення якісної та безпечної продукції, є суб'єкти господарювання. Тож безперечно необхідно приділяти значну увагу. усім складовим господарсько-правової відповідальності і проблемним аспектам визначення вини, у тому числі.
Остання має широке розуміння і заслуговує додаткових обговорень.

Відмітимо, що розробкою форм господарсько-правовоі відповідальності займалися такі вчені, як О.М. Вінник, А.П. Віхрова, А.Д. Болотова, Д.Х. Липницький, В. К. Мамутов, Л.А. Ольховик, А.Д. Ременяк, В.С. Щербина, та інші. Інститут вини $€$ вивченим у переважній більшості його проявах наступними вченими: М.M. Агарков, M.В. Бавсун, В.І. Борисов, С.В. Гончаренко, А.Ф. Зелінський, О.С. Йоффе, O.M. Костенко, Г.К. Матвеєв та ін. Натомість у межах господарсько-правової відповідальності за безпеку продукції місце та прояви вини $€$ невирішеними.

Метою статті є виявлення змісту, форми, сутності, ступеню та обсягу вини суб'єктів господарювання як умови господарсько-правової відповідальності за безпеку продукції.

Говорячи про вину суб'єктів господарювання як умову відповідальності за безпеку продукції, звертаємо увагу на загальновідомі положення, а саме, на те, що господарсько-правова відповідальність грунтується на таких важелях: 1) сукупність норм права про відповідальність суб'єктів господарських відносин; 2) господарська правосуб'єктність боржника і кредитора; 3) протиправні дія або бездіяльність господарського правопорушника, що порушують права та і законні інтереси кредитора. Нас цікавить саме ця підстава, яка складається 3 чотирьох складових: факт господарського право- 
порушення; протиправність поведінки господарського порушника; причинний зв'язок між протиправною поведінкою i завданими потерпілому збитками; вина господарського правопорушника. Саме вона виявляє негативне суб'єктивне ставлення правопорушника до прав і законних інтересів потерпілого, існуючи в формі умислу і необережності. Ці умови утворюють юридично-фактичні підстави господарсько-правової відповідальності. У господарському праві діє презумпція вини, яка полягає у тому, що "відсутність вини доводиться особою, яка порушила зобов'язання" (ст. 209 ЦК). Як зазначається в ч. 1 ст. 216 ГК учасники господарських відносин несуть господарську відповідальність за правопорушення у срері господарювання через застосування до правопорушника господарських санкцій на підставах і в порядку, передбачених законами.

Не можна ігнорувати твердження K.M. Данченко про те, що чітке уявлення про вину як один 3 елементів будь-якого злочинного діяння, здавалося б, вже сформовано у теорії права, але до цього часу вчені не можуть дійти згоди щодо правильності визначення цього поняття. П.С. Дагель зазначав, що вина являє собою внутрішню суб'єктивну сторону злочину, психічне ставлення суб'єкта до свого суспільно небезпечного діяння та його наслідків, виражених у злочині. 3 іншого боку, на думку А.В. Наумова, вина представляє собою психічне ставлення особи до вчинюваного нею суспільно небезпечного діяння та його наслідків у формі умислу або необережності. Інші автори пропонують під поняттям вини розуміти заборонене кримінальним законом психічне, у формі умислу або необережності, ставлення особи до вчинюваного суспільно небезпечного діяння та його наслідків [1, с. 150]. Однак вплив вини у відносинах господарської відповідальності має своє особливе значення, що потребує окремого дослідження, бо вина в господарських правовідносинах трансформується, що змінює загальновизнане традиційне поняття вини у праві. На думку М. С. Малєїна, яку поділяє автор, «вина являє собою сукупність неправомірних дій, окремих підрозділів підприємства чи конкретних посадових осіб, які утворюють юридичну особу». При цьому в основі відповідного поняття перебуває удавана воля суб'єкта господарювання, а не механічно складене волевиявлення працівників, 3 яких формується трудовий колектив. Подібно до того, як колективна воля не зводиться до автоматичного узагальнення індивідуальних воль, а постає у новій якості, так і вина суб'єкта господарювання $є$ самостійним поняттям. Його змістом $€$ удавана воля, і свідомість окремих учасників колективу, а не конкретних індивідів, що перебувають поза зв'язками 3 господарською організацією. В свою чергу Б. І. Пугінський розглядає вину суб'єкта господарювання як «невикористання ним наданих прав та можливостей, необхідних для належного виконання зобов'язання, а також не докладання нормальних, допустимих законом зусиль, що дозволяють запобігти правопорушенню» [2, с. 96].

Зауважимо, що оціночне тлумачення категорії «вина» здійснюється в межах психологічної та поведінкової концепцій.

При цьому основна увага акцентується на психічному ставленні особи не лише до діяння, але і до його наслідків, що виявляється у передбаченні нею наслідків вчинюваного діяння, а також у так званому вольовому ставленні до них [3, с. 88-90]. У змісті вини виділяються два моменти: інтелектуальний, який включає усвідомлення особою характеру своїх діянь і передбачення нею їх наслідків, та вольовий, який полягає у бажанні настання певних наслідків, свідомому їх припусканні, байдужому ставленні до них, розрахунку на їх відвернення, що прямо випливає із законодавчого визначення видів та форм вини.

Для визначення розуміння вини із соціально-психологічної точки зору та 3'ясування обумовленості різних іi аспектів необхідно розглянути механізм виникнення тих соціальних і психологічних складових, які визначають

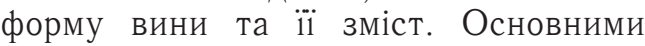
соціально-психологічними елементами 
вини $€$ інтелектуальні та вольові процеси психіки особи, що вчинює суспільно небезпечне діяння [4, с. 355].

Розглянемо згруповані в юридичній літературі доктринальні погляди щодо вини суб'єкта господарювання як умови відповідальності. Представники одного напрямку зводять вину до об'єктивних підстав відповідальності - фактів порушення зобов'язань, ігноруючи при цьому суб'єктивні підстави. Близькою до вказаної концепції є точка зору, згідно $з$ якою, господарсько-правова відповідальність базується на принципі спричинення. При такому підході зміст поняття вини настільки розширюється, а нормативно встановлені випадки обмеження чи виключення цієї умови відповідальності настільки звужують сферу іï встановлення, що суб'єктивні підстави відповідальності розчиняються в об'єктивних. В цьому аспекті підміна понять певною мірою зумовлена включенням до змісту вини випадку, як умови відповідальності. Розробники цієі концепції при обгрунтуванні своїх поглядів виходять 3 переважно необережного завдання збитків внаслідок порушення господарського зобов'язання. Прихильники іншої концепції розглядають вину як обов'язкову умову відповідальності, і тільки як виняток допускають застосування санкцій за відсутності вини.

Як наукове поняття і як суб'єктивна умова господарсько-правової відповідальності вина являє собою інтегративний засіб перерозподілу функцій і завдань відповідальності, наслідків ii застосування. Окреслені властивості вини зумовлюють виведення цього явища на завершальний етап механізму правового регулювання - стадію індивідуалізації та реалізації господарських санкцій. Іншими словами, вина є одним з інструментів, що забезпечують перехід господарсько-правової відповідальності в об'єктивному розумінні - мір, форм і засобу впливу, до встановлення та покладення на порушника додаткового обов'язку, тобто відповідальності у суб'єктивному розумінні.

В доктрині, зазвичай, в структуру вини включають дії, мотив та волевиявлення суб'єкта господарювання.
Варто підкреслити, що у господарському праві про вину правопорушника свідчать два елементи: наявність у суб'єкта господарських відносин реальної можливості діяти правомірно i попередити настання негативних наслідків (збитків) і, неприйняття ним усіх необхідних заходів для недопущення протиправної поведінки і запобігання настання збитків [5, с. 159].

В процесі виробництва бувають випадки, коли є людська недбалість, яка приводить до суспільно-небезпечних наслідків. Продукція може бути зіпсована з різних причин, і людський фактор відіграє одну з основних ролей. Дійсно, комплекс дій операторів ринку становить практичний інтерес до визначення наявності або відсутності вини у складі правопорушення. Бездіяльність можемо також віднести до причетності вини, адже замість того, щоб спробувати не допустити порушення прав споживачів, винні особи не тримають під контролем ситуацію і не поліпшують умови функціонування споживчого ринку.

Основними юридичними категоріями, які характеризують вину є зміст, форма, сутність, ступінь та обсяг.

Зміст вини є відображенням у свідомості людини об'єктивних ознак злочину, які у різних кількісно-якісних поєднаннях утворюють умисел та необережність [6, с. 82-83].

У змісті вини виділяються два моменти: інтелектуальний, який включає усвідомлення особою характеру своїх діянь i передбачення нею ї наслідків, та вольовий, який полягає у бажанні настання певних наслідків, свідомому їх припусканні, байдужому ставленні до них, розрахунку на їх відвернення, що прямо випливає із законодавчого визначення видів та форм вини. Безумовно для сфери безпеки продукції у певній мірі обидва вказаних моменти змісту вини є притаманними. Однак у процесі товаровиробництва превалює вольовий момент.

Форма як філософська категорія може бути двох видів: зовнішня, яка дозволяє провести відмінність змісту явища в цілому від усього іншого, та внутрішня, яка показує спосіб вира- 


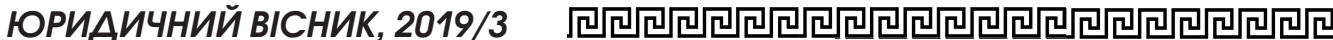

ження сутності змісту явища. Формою вини є внутрішня структура сталих зв'язків і взаємодій елементів, властивостей та процесів, що утворюють вину, а також спосіб існування і вираження іï змісту.

Вважається, що обсяг вини утворюють відображені у психіці особи конструктивні, конструктивно-органічні, кваліфікуючі, пом'якшуючі та обтяжуючі покарання обставини і ставлення до них суб'єкта. Обсяг вини являє собою сукупність психічних ставлень винуватої особи до всіх юридично важливих об'єктивних ознак, які інкримінуються суб'єктові. Отже, обсяг вини можна визначити, як психічне ставлення особи до об'єктивних ознак, які мають значення для кваліфікації вчиненого діяння за певною процесуальною нормою.

Сутність $€$ основою, що визначає загальне розуміння предметів, сукупність найбільш глибоких, стійких властивостей і відносин предметів, що визначає їх походження, характер та напрям розвитку. До такої сутності належить явище, яке, як філософська категорія, означає стосовно об'єктивної дійсності окремий предмет або процес, а стосовно свідомості - окреме психічне утворення (почуття, емоції, потреби, мотиви, думки).

Сутність вини також має розглядатися в об'єктивному та суб'єктивному аспектах. Суб'єктивна сутність вини являє собою певні аспекти мотивації поведінки, яка порушує норми права, достатні для визнання вчинених особою діянь (дій чи бездіяльності) кримінально караними. Об'єктивна (соціальна) сутність вини визначається або як психічне ставлення особи до злочину, або як негативне чи недостатньо уважне психічне іiі ставлення до основних соціальних цінностей, що виявляється у конкретному злочині. Отже, сутність вини у загальному розумінні являє собою негативне ставлення злочинця до об'єктів правової охорони. Безперечно охоронюваним мірилом на конституційному рівні в сфері безпеки продукції $€$ життя й здоров'я громадянина і саме на нього посягають неправомірні діï. В будь-якому разі байдужість особи призводить до техніко-промислових помилок і зазначається на якості кінцевого продукту (товару). Тут приведемо наступні приклади: якщо особа заздалегідь знає, що якість окремих деталей продукції чи основний інгредієнт є низької якості, але він/вона все одно його використовує й не звертає на цю проблему свого безпосереднього керівника чи органи державної влади, якщо особа дізналася в процесі роботи, що якість окремих деталей продукції чи основний інгредієнт є низької якості, але він/вона все одно його використовує й не звертає на цю проблему свого безпосереднього керівника чи органи державної влади, якщо особа підмінює якісну на неякісну продукцію. Серед наведеного виокремимо важливість емоційного стану працівника під час товаровиробництва.

Ступінь вини $є$ кількісною характеристикою сутності вини. Ступінь вини визначається відображенням у свідомості суб'єкта тих об'єктивних обставин, які в сукупності утворюють суспільну небезпеку вчиненого злочину. На ступінь вини особи, що скоїла злочин, також впливають і причини вчинення злочину, i умови, які перебували в основі формування умислу або вплинули на вчинення злочину з необережності й дістали відображення у вині особи (поєднання тяжких особистих або сімейних обставин, погроза, примус або матеріальна, службова чи інша залежність від суб'єкта злочину, випадковий збіг обставин, неправомірні дії потерпілого тощо). Отже, ступінь вини є ії кількісною характеристикою, яка залежить від тяжкості вчиненого діяння і суспільної небезпечності особи злочинця. Так, зокрема в сфері безпеки продукції ступінь вини формують належні умови праці суб'єктів господарювання, факт дотримання чи недотримання санітарно-гігієнічних норм, рівень заробітної плати.

Форми вини являють собою окреслені в законі комбінації певних ознак свідомості й волі особи, яка вчиняє суспільно небезпечне діяння. У комбінації таких ознак і знаходить своє вираження психічне ставлення особи до діяння i його наслідків. Водночас 
товаровиробник (оператор ринку) має вчиняти протиправне діяння в сфері товаровиробництва свідомо та 3 власної волі. Якщо певна особа свідомо виконує наказ іншої особи то така поведінка не може вважатися суспільно-небезпечною.

Чинне законодавство виділяє дві форми вини: умисел і необережність. Це узагальнені законодавцем поняття, які лише загалом характеризують ставлення особи до вчиненого нею діяння i його наслідків. Умисел і необережність мають свої види. Умисел може бути прямим і непрямим, а необережність проявляється в самовпевненості або недбалості. Поза цими конкретними видами не існує вини.

Усвідомлення містить у собі не тільки чітке розуміння фактичної сторони вчиненого, його зміст, характер й усі інші об'єктивні ознаки, але й певне розуміння соціальної значимості вчиненого діяння, його соціальної шкідливості. Передбачення означає, що у свідомості певної особи склалася однозначна уява про можливі або неминучі наслідки свого діяння. При цьому передбачення тут носить конкретний характер. Особа чітко усвідомлює, що саме від іï конкретного діяння настануть або можуть настати суспільно небезпечні наслідки. Вольова ознака прямого умислу становить бажання настання наслідків своєї дії або бездіяльності. Найчастіше особа прагне в цьому випадку досягти якоїсь мети, задовольнити ту або іншу потребу [7, с. 83].

Вина в нашому випадку супроводжується непрямим умислом, а ціною помилки при виробництві продукції є життя і здоров'я споживача.

При визначенні поняття вини слід ураховувати правило, закріплене в ч. 3 ст. 614 ЦК України, згідно 3 яким «особа вважається невинною, якщо доведе вжиття всіх залежних від неї заходів щодо належного виконання зобов'язання». Аналогічна характеристика винної поведінки може бути дана на підставі ч. 2 ст. 218 ГК України, хоча й іншими словами: «Учасник господарських відносин відповідає за невиконання або неналежне виконання господарського зобов'язання чи порушення правил здійснення господарської діяльності, якщо не доведе, що ним вжито усіх залежних від нього заходів для недопущення господарського правопорушення» [8].

При цьому діє принцип презумпції вини, тобто "відсутність вини доводиться особою, яка порушила зобов'язання", що передбачено ст. 209 Цивільного Кодексу України. Вина обох сторін підлягає взаємному заліку. Якщо невиконання або неналежне виконання зобов'язання виникло 3 вини обох сторін, судовий орган (суд, господарський суд, третейський суд) відповідно зменшує розмір відповідальності боржника. Це має місце і тоді, коли кредитор навмисно або 3 необережності сприяв збільшенню розмірів збитків або не вжив заходів до їх зменшення (ст. 211 ЦК) [9, с. 149-159].

Тепер розглянемо цей принцип у сфері безпеки продукції. Так в більшості випадків у профільному законодавстві вина є необхідною умовою складу правопорушення. Однак з загального правила $€$ й виключення. Згідно зі ст. 4 «Закону України «Про відповідальність за шкоду, завдану внаслідок дефекту в продукції та ст. 1209 (ЦК України), відшкодування шкоди не залежить від вини виробника продукції [10]. Відповідно до статті 16 Закону України «Про загальну безпечність нехарчової продукції» виробник і розповсюджувач не несуть відповідальності шляхом доказового спростування вичерпного переліку умов. Тобто у цих прикладах вина не є обов'язковою умовою. Це своєю чергою свідчить про повноту складу господарського правопорушення.

У науковій літературі відсутня одностайність щодо застосування понять «підстави» та «умови» господарсько-правової відповідальності. Існує думка, що принципового теоретико-прикладного значення їх розмежування фактично не існує. У зв'язку 3 цим наведені категорії ототожнюють вважаючи під підставами необхідні й достатні умови за яких виникає юридична відповідальність [11, с. 124]. Натомість ми можемо частково погодитись 3 наведеним положенням. Дійсно 


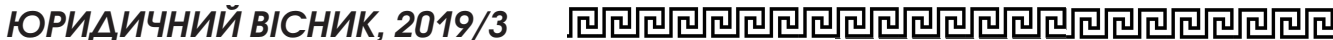

детального дослідження розмежування підстав та умов не вбачається необхідним через вивченість та обгрунтованість цього аспекту у інших галузях права. Зазначимо лише, що «умови» $€$ частиною більш широкого поняття «підстави» і тому їх не можна ототожнювати.

Таким чином, у сфері безпечності продукції визначальне має місце психо-соціальне ставлення виробників, розповсюджувачів та операторів харчової продукції. Тож вина у переважній більшості $є$ однією з необхідних умов притягнення суб'єкта господарювання до господарсько-правової відповідальності за безпеку продукції. Натомість у деяких виключних випадках наявність чи відсутність вини у складі господарського правопорушення у сфері безпечності продукції господарюючому суб'єкту необхідно довести. Саме у цьому проявляється відомий у праві принцип презумпції вини.

У статmі приділяється увага вині як умові господарсько-правовоі відповідальності за безпеку продукиіi. Здійснено науковий пошук зміcmy кониепту «вина» в сфері безпеки продукиії. Серед низки наявних у науковому обігу тлумачень поняття «вина» виявлено, що в його основі перебуває удавана воля суб'єкта господарювання, а не механічно складене волевиявлення працівників, з яких формується трудовий колектив $i$ саме ией фактор є ключовим для виокремлення у товаро-продовольчій сфері. Розглянуто оиіночне розуміння поняття «вина» в межах поведінкової та психологічної концепиій а також згруповані в юоидичній літературі доктринальні погляди щодо вини суб'єкта господарювання як умови відповідальності. Надана юридична характеристика вини у сфері безпеки продукиіі шляхом виявлення структури, змісту, форми, сутності, ступеню та обсягу. Роз'яснено, що структура вини проявляється через діi, мотив та волевиявлення суб'єкта господарювання. Встановлено, що домінуючим моментом змісту вини є вольовий.
Формою вини є випадок коли товаровиробник (оператор ринку) має вчиняти протиправне діяння в сфері товаровиробництва свідомо та 3 власної волі. Загострена увага на психо-емоиійному стані працівника під час проиесу товаровиробниитва як складника сутності вини як умови господарсько-правової відповідальності за безпеку продукиї. Встановлено, що в сфері безпеки продукиї ступінь вини формують належні умови праці суб'єктів господарювання, факт дотримання чи недотримання санітарно-гігієнічних норм, рівень заробітної плати. З’ясовано, що вина супроводжується непрямим умислом, а иіною помилки при виробництвві продукції є життя i здоров'я споживача. Розглянуто принциип презумпції вини у сфері безпеки продукиіі. Наостанок відмічено, що «умови» $е$ частиною більш широкого поняття «підстави» $i$ тому $і x$ не можна ототожнювати.

Ключові слова: вина, суб'єкти господарювання, господарсько-правова відповідальність, умови господарсько-правової відповідальності, безпека продукції.

\section{Bilyi O. GUILT OF ECONOMIC OPERATORS AS A CONDITION OF RESPONSIBILITY FOR PRODUCT SAFETY}

The article focuses on guilt as a condition of economic and legal responsibility for product safety. The scientific search for the content of the concept of "guilt" in the field of product safety has been carried out. Among a number of existing scientific interpretations of the concept "fault" it is revealed that it is the apparent will of the entity, rather than mechanically composed of the will of the workers, which make up the workforce and this factor is key for selecting in commodityfood sector. The article considers the estimated understanding of the concept of "guilt" within the framework of behavioral and psychological concepts, as well as the doctrinal views on the fault of a business entity as a condition 
of responsibility are grouped in the legal literature. Legal characterization of fault in the field of product safety is provided by identifying the structure, content, form, essence, degree and volume. It is explained that the structure of guilt is manifested through the actions, motive and will of the business entity. It is established that the dominant moment of guilt content is volitional. A form of guilt is a case when a commodity producer (market operator) must commit an illegal act in the sphere of commodity production consciously and of his own will. The attention is focused on the psychoemotional state of the employee during the process of commodity production as a component of the essence of guilt as a condition of economic and legal responsibility for product safety. It is established that in the field of product safety, the degree of guilt is formed by the appropriate working conditions of economic entities, the fact of compliance or non-compliance with sanitary and hygienic standards, the level of wages. It is found that the fault is accompanied by indirect intent, and the price of error in the production of products are the life and health of the consumer. The principle of presumption of guilt in the field of product safety is considered. Finally, it is noted that "conditions" is part of the broader concept of "grounds" and therefore cannot be identified.

Key words: guilty, business entities, economic and legal responsibility, conditions of economic and legal responsibility, product safety.

\section{Література}

1. Вереша Р.В. Проблеми суб'єктивної сторони складу злочину: монографія. - К.: Arepma, 2018. 432 c.
2. Заярний О. Вина в системі умов господарсько-правової відповідальності. Вісник Київського національного університету імені Тараса Шевченка. Юридичні науки. 2010. Bun. 84. С. 93-98.

3. Вереша Р. В. Сучасні теорії (кониепціі) вини в науці кримінального права. Вісник Академії адвокатури України. 2015. T. 12. № 1(32). С. 79-94.

4. Бурдін В. М. Зміст вини: проблема співвідношення інтелектуальних та вольових моментів. Вісник Львівського університету. Серія юридична. 2012. Bun. 56. C. 355-365.

5. Матвійчук А.В. Адміністрування у сфері господарської відповідальності (теоретичний аспект). Юридичний вісник. 2018. 4 (49). C. 157-162.

6. Науково-практичний коментар Кримінального кодексу України (від 5 квітня 2001 року) / A. М. Бойко та ін. / за ред. М. I. Мельника, М. I. Хавронюка. 6- те вид., перероб. та допов. Киї: Юридична думка, 2009. 1236 c.

7. Кримінальне право України. Загальна частина: текст лекцій: Закон. Злочин. Відповідальність / В.О. Туляков, Н.A. Мирошниченко, Д.О. Балобанова; НУ ОЮА. Одеса: Юридична література, 2014. 128 c.

8. Господарський кодекс України від 16.01.2003 р. № 436-IV. Відомості Верховної Ради України. 2003. № 18. № 19-20. № 21-22. Cm. 144 .

9. Швидка Т.І. Удосконалення механізму господарсько-правової відповідальності у сфері економічної конкуренції. Економічна теорія та право. 2016. № 2. С. 149-159.

10. Про відповідальність за шкоду, завдану внаслідок дефекту продукції: Закон України від 19.05.2011 р. № 3390-VI. Відомості Верховної Ради України. 2011. № 47. Cm. 531 .

11. Парасюк В.М. Склад правопорушення як підстава цивільно-правової відповідальності. Порівняльно-аналітичне право. 2017. № 6. С. 124-127. 